\title{
Can conflict- management be effective in the Israeli- palestinian conflict? the inaccurate comparison with the protracted conflict of Cyprus
}

\begin{abstract}
The article focuses on current conflict- management of the Israeli-Palestinian conflict in comparison with another protracted conflict, namely the one between Turkey and Cyprus. It suggests that the prevalent approach regarding both conflicts is conflict management instead of conflict resolution and not conflict management aiming at conflict resolution. However and in contrast to the Cyprus conflict, the contemporary catalyst characteristics of the Israeli-Palestinian make it almost impossible to have a successful conflict management. As such are mentioned the attitude of Israel within the conflict because of its internal structural reforms, the international framework and the huge imbalance of power between the two rivalries.
\end{abstract}

Volume I Issue 4 - 2017

\section{Themistoklis Tzimas}

University of Macedonia, Greece

Correspondence: Themistoklis Tzimas, University of Macedonia, Greece, Email themis.tzimas@gmail.com

Received: November 04, 2017 | Published: December 22, 2017

\section{Introduction}

A string of recent events brought again at the forefront the deteriorating- if not completely reversed, towards conflict-IsraeliPalestinian peace process; from the election of Donald Trump and his -at least partial or potential-detachment from the two-state solution as well as the recognition by the US of Jerusalem as the capital of the US, ${ }^{1}$ to the Israeli, continuous settlement expansion ${ }^{2}$ and from the discussion about an ongoing third Intifada to the Israeli hostility against any attempt of the Palestinian authority to upgrade its status internationally, as well as the debate for a Jewish state annexing West Bank, the prospects of a successful peace process are bleak.

The suggestion of this article is that the contemporary prevalent on the ground, approach to the issue of Israeli occupation and to the subsequent conflict is that of conflict management not aiming at conflict resolution, but instead of conflict resolution. While such an approach in principle is not necessarily doomed to fail, in terms of softening aspects of a conflict, the argument of the article is that given-mainly but not solely- the specific subjective conditions of the Israeli-Palestinian conflict, such a potential cannot be materialized.

Therefore, the argument continues that the failure both regarding the resolution of the conflict and in terms of a peaceful management, leads inevitably to a vicious circle of occupation and violence. In order to stress the unique conditions of the Israeli-Palestinian conflict, which makes it so difficult to become even manageable- let alone to be resolved- methodologically, a comparison with the conflict in Cyprus is chosen, since the latter falls within the same broader type of protracted conflicts too. The case of Cyprus, despite deing a similar one- in the sense of constituting a protracted conflict as well as of failure to resolve the roots of the conflict- has been successful in terms of conflict management.

The two cases, apart from the similarity in the sense of their general categorization share common elements also in terms of their origins. In both of them, inter-communal grievances in combination with the

${ }^{1}$ Baker P, Landler M. Trump, Meeting With Netanyahu, Backs Away From Palestinian State. USA: The New York Times; 2017.

${ }^{2}$ Beaumont P. Israel announces 2,500 more West Bank settlement homes, the guardian. 2017. historical impact of the colonial era can be traced in their origins. Both also involve a number of psychological and identity-based paragons which constitute a structural element of such type of conflicts, ${ }^{3}$ as well as the variety of elements which are included in the greater theoretical school of human needs theory. ${ }^{4}$ Profoundly, the defining, common characteristic in both conflicts is the prolonged occupation, the existence of which leaves little hope regarding conflict resolution.

Despite these analogies, the two conflicts have followed in the last decades different "paths": in Cyprus, conflict management has successfully prevented the outbreak of new violence, since 1974 , while in the Israeli-Palestinian conflict, violence is omnipresent. The diverse developments in the two conflicts can be blamed on several distinct identities of them. For example, in the Israeli-Palestinian conflict there are no "motherlands" in the sense of the Cyprus conflict, especially since the Palestinians under the leadership of the PLO adopted the "Palestinian cause" doctrine as an autonomous cause within the framework of the "Arab unity", ${ }_{5}^{5}$ the international, regional framework is different and also the general balance of power- not only military but also economic, diplomatic and political- is distant between the two cases.

The main argument of the article, which orientates out of the comparison of the analogies and of the disanalogies between the two conflicts is that the main reason for the contradictory outcome of the attempted conflict management in the two cases can be-in the end-condensed into the different subjective approaches: while in the ${ }^{3}$ Bar-Tal D. From Intractable Conflict through Conflict Resolution to Reconciliation: Psychological Analysis. Political Psychology. 2000;21(2):351365

Coleman P. 'Intractable Conflict'. In: Deutsch M, Coleman P, editors. The Handbook of Conflict Resolution. USA: Jossey-Bass; 2000. p. 428-450.

${ }^{4}$ The human needs theory traces at the root-causes of conflicts the unmet basic human needs of psychological, social and physical nature.

Burton J. Conflict: Human Needs Theory. St Martins, USA; 1990.

${ }^{5}$ This autonomous position was further enstrengthened in the course of years, in light on the one hand of the development of the Palestinian struggle which became the dominant one in the Arab world and on the other hand because of the complications and open conflicts with other Arab states or the manipulation of the Palestinian cause.

Karsh E. The Palestinian's Real Enemies. The Middle East Quarterly. 2014:21(2) 
Cyprus conflict, a common perspective from both sides for effective conflict management exists, in the Israeli-Palestinian conflict such a stance is absent or at least is much less shared-especially- by the most powerful part of the two.

A parenthetical but still critical distinction, which transcends the article, is the one between conflict management instead of conflict resolution and conflict management aiming at conflict resolution. The latter is based on a "realistic optimism" suggesting that the resolution of a conflict can be achieved but prerequisites a step-by- step process: "a protracted conflict lingering over time with violent hostilities, such as the Arab-Israeli conflict, cannot be resolved without a prerequisite prolonged and successful conflict management. ${ }^{6}$ The former orientates from the assumption that the conflict cannot be resolved and therefore a management aiming at easing the tensions is the choice, until the conditions of the conflict have changed.

The "management-instead-of-resolution" approach is not unknown to public debate. As Hugh Miall argues, a certain part of analysts suggest that the resolution of certain conflicts is unrealistic: "the best that can be done is to manage and contain them, and occasionally to reach a historic compromise in which violence may be laid aside and normal politics resumed". ${ }^{7}$ Conflict management of this second type is presented thus as a method of "damage control".

Historically, it has been proven that it is a delicate synthesis of conditions, which determines the success or not of both aspects of conflict management. Therefore not all conflicts can be eased through conflict management. The common characteristic, both in relation to Cyprus as well as in relation to the Israeli-Palestinian conflict is that the prevalent approach has been-implicitly-conflict management instead of conflict resolution.

In terms of structure of the article, it begins with a brief reference to the concepts of conflict management and conflict resolution. The two concepts are then applied comparatively on the occupation of $\mathrm{N}$. Cyprus, as well as on Israeli occupation of the Palestinian territories and the conclusion about the critical differences are reached.

\section{Conflict management and conflict resolution in protracted conflicts}

The distinction between conflict management and conflict resolution is based on the potential elimination or not of the fundamental causes of the conflict. "Conflict resolution involves the reconciliation or elimination of fundamental differences and grievances underlying a conflict", while conflict management "..Means controlling, limiting, and containing conflict behavior in such a way as to make it less destructive or violent" 8

The terms are used in a flexible and sometimes even confusing way. ${ }^{9}$ The main point of distinction lies in the actual ending of the

${ }^{6}$ Yaacov Bar-Siman-Tov. The Arab-Israeli Conflict: Learning Conflict Resolution. Journal of Peace Research. 1994;31(1):75.

${ }^{7}$ Miall H. Conflict Transformation: A Multi-Dimensional Task. Berghof Handbook of Conflict Transformation. 2004

${ }^{8}$ Bar-Siman-Tov. The Arab-Israeli Conflict. 1949. 75 p.

9It must be stressed here that some of the ways to resolve a conflict are based on the maximization of the destructiveness of the conflict, such as for example through ethnic cleansing and genocide. It is obvious that this article does not include in its analysis such means but only those which have the potential for restraining and easing the conflict and the violence.

McGarry J, Leary BO. Introduction: the macro-political regulation of ethnic conflict. In: McGarry J, Leary BO, editors. The Politics of Ethnic conflict Regulation. UK: Routledge; 1993. 4 p. conflict which is implied by the term resolution; whereas conflict management implies the process which through a set of activities or techniques could potentially ease the underlying causes of the conflict and in some cases even eventually remove them. ${ }^{10}$

The concept of conflict management is based on an assumption that by gaining time, the underlying causes of a protracted conflict might ease so that the later gradually de-escalates, up to the extent that a resolution of the conflict can be achieved. "Successful" conflict management emerges out of the coexistence both of internal and external paragons, such as for example are the realization of the inadequacy of resources on behalf of the parties of the conflict, the cost of conflict which is out weighting the value of it, the dangers from the escalation, as well as the existence of external constraints and mechanisms suppressing the development of the conflict. ${ }^{11}$

On such grounds, even if the parties of a given conflict find it impossible to resolve their underlying differences they willsupposedly-find it more convenient to manage them. As Wallenstein suggests conflict management: "typically focuses on the armed aspects of conflict: bringing the fighting to an end, limiting the spread of the conflict and, thus, containing it. ...conflict resolution is more ambitious, as it expects the parties to face jointly their incompatibility and find a way to live with or dissolve it". ${ }^{12}$

The methods of conflict management are neither stable through time, nor limited. In fact they evolve in praxis and over time. On the contrary, they are extended and include a variety of alternatives, which attempt either to repress the conflict or to create a framework for its guidance towards an environment of greater mutual understanding.

As methods of this type are mentioned "traditional diplomatic, military, and economic means of influence, up to and including the threat or use of force...", intervention from international organizations, institutions, NGO's to the so-called citizens' diplomacy. ${ }^{13}$

Another tool for the successful management of a conflict instead of the suppression and regulation mechanisms is the institutionalization of the conflict, because it bears the potential of "internalization" of the management goals and methods by the parties of the conflict, as well as of them learning that the absence of conflict is mutually beneficiary for them. ${ }^{14}$ Such a "learning" procedure supposedly will gradually not only suppress violence but will also create more sustainable conditions of trust and cost- benefit relations, eventually eradicating the causes of conflict. Other points of view emphasize the role of negotiations and mediation. ${ }^{15}$

Within the framework of the institutionalization procedure, the assumption- which often is proven empirically correct- is that power- sharing institutions between the rivals can help in diffusing the conflict. ${ }^{16}$ Although this procedure is most common in internal

${ }^{10}$ Mitchell C. Handbook of Conflict Resolution: The Analytical ProblemSolving Approach. Institute for Conflict Analysis and Resolution; 2005:6.

${ }^{11}$ Bar-Siman-Tov. The Arab-Israeli Conflict. 1948. 76 p.

${ }^{12}$ Wallensteen P. Understanding Conflict Resolution: War, Peace and the Global System. India: Sage Publications; 2002. 53 p.

${ }^{13}$ Stern PC, Druckman D. International Conflict Resolution After The Cold War. National Academy of Sciences. 2000:5-6.

${ }^{14}$ Bar-Siman-Tov. The Arab-Israeli Conflict. $80 \mathrm{p}$.

${ }^{15}$ Bercovitch J, Anagnoson JT, Wille DL. Some Conceptual Issues and Empirical Trends in the Study of Successful Mediation in International Relations. Journal of Peace Research . 1991;28(1):7-8.

${ }^{16}$ Hartzell C, Hoddie M. Institutionalizing Peace: Power Sharing and PostCivil War Conflict Management. American Journal of Political Science. $2003 ; 47(2): 318-319$. 
conflicts it is also useful, with the appropriate specifications in relation to international conflicts as well, through the adoption of regional, power-sharing mechanisms. ${ }^{17}$

The success or not of conflict management lies at large with the specific conditions of the conflict, given that these are unique in each case. Sociopolitical, historical, local, and psychological and powerbalance nature ${ }^{18}$ variables are all to be taken into account when assessing the effectiveness of case management. On top of them, obviously the root- causes of conflicts are of the utmost importance too. ${ }^{19}$

In addition, time plays a crucial role; in other words at each specific phase of the conflict, briefly described as a cycle divided among "structural instability...social unrest and violence, and finally.. sustainable peace and conflict resolution", the success of conflict management is determined by different factors. ${ }^{20}$

This latter reference does not imply a mechanical approach but on the contrary that on the one hand there is the potential of re-fueling of the conflict even after conflict resolution and of course after successful management of it and on the other hand that a conflict could remain "trapped" in the outbreak of violence for an extended period of time.

All of the fore-mentioned means for conflict management, as well as the different variables and conditions "on the ground" are eventually depicted at the level of maturization of the will of the conflicting parties to reach a resolution or at least a "freezing" of the conflict. The argument of the article is that the combination of highly diversified factors and conditions eventually comes down to the formation of structural and strategic, subjective tendencies or even decisions of the implicated parts towards the conflict. The terms "structural and strategic" are chosen in order to portray a lasting approach- although not necessarily unchangeable-which is not simply the circumstantial decision of a government but a transcending different political leadership's stance which more or less constitutes state policy. It also indicates that it is the outcome of several paragons with deep roots within each one of the conflicting parts.

The examination of these subjective tendencies, as well as of their formation is necessarily conducted within the framework of each specific type of conflict. It is a certain type which poses the most difficult challenges in terms of conflict management-as well as resolution: the so- called "protracted" or enduring conflicts, which due to specific conditions resist the different techniques of conflict management, falling back to repeated phases of violence. ${ }^{21}$ There are several descriptions of protracted conflicts mainly referring to the duration and the continuity of them, from ten to twenty years and two

\footnotetext{
${ }^{17} \mathrm{The} \mathrm{EU}$ constitutes such a paradigm, as among other reasons it was captured as a power-sharing regional institution, in furtherance of peace in the continent. ${ }^{18}$ Pearson F. Dimensions of Conflict Resolution in Ethnopolitical Disputes. Journal of Peace Research. 2001;38(3):275-277.

${ }^{19}$ Gurr TR. Peoples against States: Ethno political Conflict and the Changing World System'. International Studies Quarterly. 1994;38(3):347-365.

${ }^{20}$ Thruelsen PD. International Organizations: Their Role in Conflict Management. In: Thruelsen PD, editor. Royal Danish Defence College, 15 p.

${ }^{21}$ Azar E. Protracted International Conflict: Ten Propositions. In: Azar E Burton JW, editors. International Conflict Resolution. Wheat sheaf Book, 1986. p. 27-39.

Goertz G, Diehl PF. The Initiation and Termination of Enduring Rivalries: The Impact of Political Shocks. American Journal of Political Science. 1995;39:30-52.

Kriesberg L. Intractable Conflicts. Peace Review. 1993;1(4):417-421.
}

or more episodes of military collision. ${ }^{22}$

At the core of them can be traced a past which is galvanized by conflict and grievances, a present which is defined by the use of coercive means and a future which is most likely to be determined by similar if not identical means. ${ }^{23}$

The fore- mentioned correct but still relatively abstract approach does not depict holistically, the diversified nature of conflicts which is transcended by the multi-dimensional formation of each conflict's causes and their differentiated development over time, leading inevitably to goal incompatibility between the different parts. ${ }^{24}$ Azar's analysis on protracted conflicts offers some insight regarding their root- causes by suggesting that they are not only built on conflicting identities but also on structural inequalities and long standing domination of one group over another. ${ }^{25}$

The incompatibility of goals indicates an explanation of the failure not only of conflict resolution but potentially of conflict management as well. The reason for conflict management failure therefore may be traced both in the inner causes of the conflict and in a- perceived as inherent- collision of goals.

In the next parts a comparative examination of two cases is attempted: the one between the "Cyprus case" and the IsraeliPalestinian conflict in order to identify reasons for the failure not only of resolution but also of management in the latter case.

While there are significant differences between the two cases, they also bear some important similarities: they are both protracted conflicts, they involve two communities, they gained high intensity in the post- colonial process, the existence of occupation constitutes a decisive event, third actors play a crucial role and in addition, a profound imbalance of military power exists between the occupying force and the victim of the occupation.

\section{Cyprus: a successful case of conflict- management, despite the lack of resolution}

A short reference to the history of the Cyprus conflict will take place in order to provide very briefly some of its main characteristics and similarities with the Israeli-Palestinian one. Cyprus lies at the crossroads of three continents-Asia, Africa and Europe-40 miles away from Turkey and 600 miles away from Greece. While Greeks were the first settlers and still the majority of the island, the long line of occupying forces, states and dominions and especially the Ottoman rule (1571-1878) led to the formation of a Turkish- Cypriot minority, which constitutes up to $18 \%$ of the total population, while Greek Cypriots almost 80\%. ${ }^{26}$ Cyprus became a British colony from 1925 to

${ }^{22}$ Diehl P. Contiguity and Military Escalation in Major Power Rivalries. Journal of Politics. 1985;47(4):1203-1211.

Huth P, Russett B. General Deterrence between Enduring Rivals Testing Three Competing Models. American Political Science Review. 1993;87(1):61-73.

${ }^{23}$ Bercovitch J, Patrick M. Regan, The Structure of International Conflict Management: An Analysis of the Effects of Intractability and Mediation. The International Journal of Peace Studies. 1999:4(1).

${ }^{24}$ Mitchell. Handbook of Conflict Resolution: The Analytical Problem-Solving Approach. 1996:11.

${ }^{25} \mathrm{Azar}$ E. The Theory of Protracted Social Conflict and the Challenge of Trans forming Conflict Situations. Monograph Series in World Affairs. 1983;20:8199.

${ }^{26}$ Hadjipavlou-Trigeorgis M, Trigeorgis L. Cyprus: An Evolutionary Approach to Conflict Resolution. The Journal of Conflict Resolution. 1993;37(2):342343. 
1960, when independence was declared, following the anti-colonial struggle which was led by the Greek-Cypriot community-albeit causing a number of cleavages within this community on the basis of the political perspective of the anti-colonial fight. ${ }^{27}$

Divisions between the two communities date back to the anticolonial struggle and even more to its armed phase since 1955 under the guidance of EOKA, ${ }^{28}$ with the Greek Cypriot community asking for union- "enosis"- with Greece, while the Turkish Cypriot asked for partition-taksim. ${ }^{29}$ The inter-community rivalries were further heated by the British interference as the colonial power and by the Turkish state, which for a variety of reasons opposed the union of Cyprus with Greece. The long history of rivalry between the two motherlands ${ }^{30}$ as well as their contradictory interests, intensifying divisions and historical perspectives over Cyprus have further fueled tension up until now. ${ }^{31}$

The interference of several outside forces, both Great Powers and regional states, eventually led to a truncated, unsatisfactory for both communities and mainly for the majoritarian, independence. While the union and partition claims were officially off the table, the new institutional framework at the constitutional level was dysfunctional, tending towards disintegration instead of integration, deepening the inter-communal grievances and mistrust. ${ }^{32}$ The new state not only failed to strengthen a common "Cypriot" identity but on the contrary contained as an inherent element of its provisions the continuation of the inter-communal divisions establishing them at a constitutional basis. $^{33}$

In addition and even worse, the declaration of independence was followed by the Treaty of Guarantee, which gave to the UK, Greece and Turkey the status of guaranteeing powers, military presence and the "right to take action with the sole aim of re-establishing the state of affairs created by the present treaty". ${ }^{34}$ The idea was that the

${ }^{27}$ Katsourides Y. Nationalism, anti-colonialism and the crystallization of Greek Cypriot nationalist party politics. Commonwealth \& Comparative Politics. 2013;51(4):503-523.

${ }^{28}$ National Organization of Cypriot Fighters-Ethinki Organosi Kyprion Agoniston in greek.

${ }^{29}$ Kontos M. Introduction, Foreign Interventions and Domestic Perceptions: An Analytical Framework. In: Kontos M, Theodoulou SC, editors. Great Power Politics in Cyprus: Foreign Interventions and Domestic Perceptions. Cambridge Scholars Publishing; 2014. 4 p.

${ }^{30} \mathrm{Greco}$-turkish relations have been mainly volatile and in several occasions for no obvious reasons. Certain analysts identify within this difficult relationship emotional or even irrational relations.

Kissinger H. Years of Renewal. USA: Simon and Schuster; 2000. p. 192-195.

The relations of the two states underwent eras of cordial co-existence as well as of profound hostility.

Heraclides A (2011) The Essence of the Greeek-Turkish Rivalry: National Narrative and Identity, (Greece Paper No.51.51.51.51 Hellenic Observatory Papers on Greece and Southeast Europe Hellenic Observatory Papers on Greece and Southeast Europe Hellenic Observatory Papers on Greece and Southeast Europe Hellenic Observatory Papers on Greece and Southeast Europe.

${ }^{31}$ Richmond O. Ethno-Nationalism, Sovereignty and Negotiating Positions in the Cyprus Conflict Obstacles to a Settlement. Middle Eastern Studies. 1999;35(3):42.

${ }^{32}$ Kitromilides P. From the dialectics of intolerance to an ideology of ethnic coexistence. In Small states in the modern world. In: Worseley P, Kitromilides P, editors. Stavrinides Press, 1977.

${ }^{33}$ Christofi E. Negotiations for a Cyprus settlement-An historical review. Cyprus News Agency. 2017.

${ }^{34}$ Carment DC et al. Who Intervenes? Ethnic Conflict \& Interstate Crisis. USA The Ohio State University Press; 2006. 183 p. multilateral treaty and the presence of three gurantor states would prevent both "enosis" and "taksim", through the mutual exclusion of these ambitions and a balance of power or terror. In fact, when added with the dysfunctional constitution it only intensified the entropy of the situation by internalizing- objectively- within Cyprus the internal political developments and the foreign policies of three other states.

Therefore, one plus three critical factors in relation to the immanence of the conflict in Cyprus can be identified. It is obvious that the initial agreement about independence as well as the Treaty of Guarantee were highly problematic in terms both of failing to satisfy any of the involved sides and of failing to promote the reconciliation procedure. Both sides felt that their cause was betrayed while the benefits from the concessions were far from obvious. ${ }^{35}$ In addition, they actually bound Cyprus to the plans of Greece, Turkey and UK. It is characteristic of failure or denial to foresee even the short- term consequences when weak or hazy state institutions are adopted.

This first problematic element which determined the future developments in the Cyprus conflict orientated from two other primary conditions: the divergent courses and gradually identities of the two communities, which over time were finding their co-existence more as a problem than as a natural and positive element. That created a negative stance which formulated "fertile ground" for a vicious circle of violence.

The second primary condition was the implication of a number of foreign forces with defining role over the two communities and contradictory ambitions regarding the issue. The UK acted as the former colonial power while Greece and Turkey saw in Cyprus the extension of their own national interests and identities. In such a framework, the internal divisions met with the regional actors' goals, leading to a spiral of deteriorating conditions.

A third condition, again orientating from the international environment was the impact of the Cold War. That cannot be fully analyzed here and in addition critical documents have not yet been fully disclosed. This is why different estimates have been proposed, ranging from the assumption that there was complete knowledge and approval on behalf of the US administrations of the plan for a coup detat in Cyprus by the Greek junta and a Turkish invasion, ${ }^{36}$ to more "moderate" perceptions arguing that the US did not intend to such developments but was rather proven incapable of preventing them. ${ }^{37}$ What constitutes common ground though is that the US concerns about the potential Soviet influence on Archbishop and leader of the Republic of Cyprus, Makarios played a crucial role in the neative developments in Cyprus.

In such a framework, the structure of the new state combined with specific political choices and outside interferences fueled inter-communal conflict. This was the case in 1963 and 1964 after an attempted constitutional amendment which was introduced by Archbishop Makarios. ${ }^{38}$ The tentative and delicate balance, which

${ }^{35}$ Tocci N, Kovziridze T. Cyprus: Europeanization and Conflict Resolution. In: Bruno Coppieters, et al. editors. Case Studies from the European Periphery. Belgium: Academia Press; 2004. 68 p.

${ }^{36}$ Stern L. The Wrong Horse: The Politics of Intervention and the Failure of American Diplomacy. USA: Times Books; 1977. 80 p.

Scherer JL. Blocking the Sun: The Cyprus Conflict, Minneapolis: Minnesota Mediterranean and East16 European Monographs. 1997:39.

Hitchens C. The Trial of Henry Kissinger. USA; 2001. 84 p.

${ }^{37}$ The personal approach of the writer lies closer to the first approach.

${ }^{38}$ Volkan V. Cyprus: War and adaptation: A Psychoanalytic History of Two Ethnic Groups in Conflict. Charlottesville: University Press of Virginia; 1979. 
was combined with Turkish threats for intervention and EOKA B' attacks, ${ }^{39}$ was eventually destroyed following the Greek juntasponsored coup in Cyprus which provided an alibi for the Turkish intervention of 1974 and the occupation of the Northern part until today. It was on the grounds of an already partially divided Cyprus, with Turkish Cypriot enclaves already established and Greek-Cypriot nationalistic acts culminating, the division and the occupation which hold until today took place.

From the outbreak of the first inter-communal disputes- before the Turkish intervention- up to now-more than four decades after the Turkish intervention- continuous rounds of negotiations have taken place, none of which-until now-managed to resolve the conflict. While before the intervention the key-issue of the negotiations was the autonomy of the Turkish-Cypriot community within a unitary state, shortly after the intervention as basis for the negotiations was accepted a federal structure of the state, ${ }^{40}$ labeled as "a bi-zonal, bi-communal federation and agreed on a single sovereignty, a single citizenship and a single international personality for the federal Cyprus". ${ }^{41}$

For about three decades the diplomatic stalemate was unreachable. In the beginning of the 00 's things seemed to be potentially changing. The so-called "Annan plan" was supposedly the closest effort to a negotiated solution, until that point. Still, it failed because it was rejected by the Greek-Cypriot community in a double referendum, in both communities, while it was approved by the Turkish-Cypriots. Apart from the variety of sentiments which led to this development, the existence of dysfunctional provisions of the plan and its failure to tackle a number of heating issues contributed to its rejection by the Greek-Cypriots.

After the failure of the "Anan plan", it was only recently that new hope for the resolution of the conflict emerged in the latest negotiations round which began in 2016, between president Anastasiades and the leader of the Turkish-Cypriot community, Akinci. Despite the almost "euphoric" sentiments arising during the negotiations ${ }^{42}$ the expectations became gradually somewhat less optimistic, following a "blame- game" between the two communities and the two equivalent mother- countries, Greece and Turkey. ${ }^{43}$ Eventually, the negotiations failed.

It is important to notice here that the de facto created situation of the occupation on the ground as well the recognition by Turkey of the so-called Turkish Republic of Northern Cyprus, further undermined the potential of a conflict resolution, shifting the basis of negotiations. In other words not only the initial, inter-communal differences were not resolved but even worse, new reasons complicating the dispute came up, due to the de facto created conditions. The interpretation of how in praxis a bi-zonal federation is to be implemented, the massive presence of Turkish army, the demographic change due to the Turkish settlers of Northern Cyprus, international guarantees, the new constitution, the member of refugees who will return to the northern part, the settlers from Turkey who will remain in Cyprus following a potential solution, the transfer of occupied territories to the

${ }^{39}$ Mallinson W. For a description of the events: Cyprus: A Modern History. Tauris IB \& Co Ltd; 2005. p. 36-37.

${ }^{40}$ Hadjipavlou-Trigeorgis M, Trigeorgis L. Cyprus: An Evolutionary Approach to Conflict Resolution. 1993:345.

${ }^{41}$ Cyprus Ministry of Foreign Affairs, Latest Developments. 2017.

(http://www.mfa.gov.cy/mfa/mfa2016.nsf/mfa09_en/mfa09

en?OpenDocument, access at 9-4-2017)

${ }^{42}$ Tzimitras H, Gurel A. Cyprus Settlement Negotiations: From Euphoria to Reality. Turkish Policy Quarterly. 2016;15(1):51-53.

${ }^{43}$ Stefanini S. Greek minister blamed for derailing Cyprus talks. USA: Politico; 2017.
Greek-Cypriot community, the administration, the economic cost of reunification, as well as formalistic but still highly symbolic matters, such as the way that the leader of the Turkish-Cypriot community is addressed, have prevented until now the resolution of the conflict despite the numerous negotiations rounds, ${ }^{44}$ as well as the property issue are new-in the sense that they emerged after the 1974 invasionissues, which further complicate the resolution procedure.

Even further, the interpretation of the main concepts which emerged as common ground for a potential resolution of the conflict has led to confrontations and interpretative speculations, suggesting that in fact the consecutive peace plans lead to a confederation instead of a federation or even to a new state instead of the re-unification of the already existing "Republic of Cyprus". The issue is crucial both legally and politically speaking and was raised both in legal and in political terms. It was complicated, because of the Annan plan too, which seemed to imply the merging into a new, successor state of the Republic of Cyprus and of the non-recognized internationally, Turkish Republic of Northern Cyprus-TRNC. ${ }^{45}$ This potential outcome, in political terms-which are mainly of interest here-fueled the fears of the Greek-Cypriot community, in the sense of losing their sovereign state- even de facto mutilated- in favor of a new state with a strong presence of the Turkish army.

In such a framework of mistrust, even the admission of the Republic of Cyprus into the EU and the so- called "Europeanization" ${ }^{46}$ further complicated the potential resolution, raising fears to the TurkishCypriot community for a potential renewed version of "enosis", in the greater framework of the EU. ${ }^{47}$ It has been considered at large by the Turkish-Cypriot part as a reinstatement or re-ascertainment of a policy on behalf of the Greek-Cypriot part for resolution of the conflict solely through the maintenance of the Republic of Cyprus, which, according to the Turkish-Cypriot community undermines its own rights.

On the basis of the fore-mentioned reasons, traced both before and after the 1974 invasion, a structural, strategic, or in other words "fundamental" reluctance of the involved actors and subsequently a negative for the resolution of the conflict environment has been established. ${ }^{48}$ The focus is on "adversarial lens" as is for example profoundly the case regarding security issues and the presence of foreign troops. ${ }^{49}$

${ }^{44}$ Hadjipavlou-Trigeorgis M, Trigeorgis L. Cyprus: An Evolutionary Approach to Conflict Resolution. 1993:345-346.

${ }^{45}$ Sözen A, Özersay K. The Annan Plan: State Succession or Continuity. Middle Eastern Studies. 2007;43(1):136-137.

${ }^{46}$ Europeanization in such a context is described as "a process that is activated and encouraged by European institutions-primarily theEuropean Unionby linking the final outcome of a conflict to some degree of integration into European structures for the opposing sides".

Coppieters B, Emerson M, Huysseune M, et al. Europeanization and Conflict Resolution: Case Studies from the European Periphery. 2004:2.

${ }^{47}$ Muftuler-Bac M, Guney A. The European Union and the Cyprus Problem 1961-2003. Middle Eastern Studies. 2005;41(2):281-289.

${ }^{48}$ Tocci N, Kovziridze T Cyprus, Coppieters B, et al. Europeanization and Conflict Resolution: Case Studies from the European Periphery. 2004:63.

${ }^{49}$ Hadjipavlou-Trigeorgis M, Trigeorgis L. Cyprus: An Evolutionary Approach to Conflict Resolution. 1993:347.

This is an objective observation. Within it, an assessment regarding the major responsibility for the non- achievement of a resolution can be of course conducted. This is not the focus of this article however. Up to the extent that it can parenthetically only be mentioned, the position of the writer is that in the post- 1974 phase, the defining factor for the non- resolution of the conflict lies with the persistence of Turkey to maintain its military presence in the island, contrary both to the treaty of guarantees and to fundamental norm of international law. 
After all, on top of the already existing inter-communal grievances and disputes, the long lasting occupation added further complications. The post-1974, de facto created situation regarding the presence of Turkish army, the trauma inflicted to the Greek-Cypriot community, the building of state-like authorities in the Northern part, the transfer of settlers and the decades-old separation of the two communities have further eroded the prospects of conflict resolution. The lack of trust and the desire of its community to maintain what it considers as its assets are prevalent in the negotiations procedures.

The potential resolution of the Cyprus conflict implicates and would prerequisite commonly accepted answers to a number of crucial legal and political questions: sovereignty and occupation; state lawfulness- regarding the Northern part-and state succession; settlers and the right to return of the Greek-Cypriot refugees; fear, insecurity and grievances; exploitation of natural resources and outside interferences by motherlands or other international actors. This mixture of legal, political, international and psychological issues, combined with the de facto alternation of the status quo through the use of force complicate conflict resolution.

All these come down to inherently different, if not contradictory self- perceptions and narratives of the two communities in the face of the crisis: "For the Greek Cypriots a more highly integrated transcommunal state is desirable but the diminution of sovereignty appears as a disadvantage since they are in control of the internationally recognized sovereign state. For the Turkish Cypriots the priorities are reversed. The pull of European integration has an important effect on Cypriot developments, but that too is fractured. The pattern of rewards and sanctions affect the various actors differently, given their asymmetrical position relative to the EU ranging from established full membership in the case of Greece, to recently achieved accession for the republic of Cyprus, to Turkey's candidate status, to the limbo in international law of Turkish Northern Cyprus". ${ }^{50}$ Strategic disagreements regarding the institutional formation, as well as suspicion and prevalent historic grievances have made it until now impossible to achieve a breakthrough in the efforts for a settled resolution

What is crucial though regarding the theme of the article is a contradictory tendency: on the one hand, the resolution of the conflict in Cyprus is yet to be achieved and even worse, since the initial stages of inter-communal grievances and disputes, new conditions deteriorating the prospect of peace have emerged. Despite the intensive negotiations over time, the resolution of the conflict seems highly unlikely.

On the other hand though, conflict- management in the post-1974 era has been proven very effective. Apart from some specific, sporadic incidents of violence and despite some threats from time to time from the side of Turkey, inter-communal violence is practically nonexistent. On the contrary, the first decade of the $21^{\text {st }}$ century brought up to a significant extent a normalization of the relationship of the GreekCypriots with the Turkish-Cypriot, which has not frozen despite the lack of resolution or the re- emergence of nationalistic movements. Several reasons for such a development may be identified.

In terms of bringing the resolution of the conflict closer conflict management it certainly has not been effective. In terms of easing the

${ }^{50}$ Moulakis A. Power-Sharing and its Discontents; Dysfunctional Constitutional Arrangements and the Failure of Annan Plan for a Reunified Cyprus. Middle Eastern Studies. 2007;43(4):532. tension though, it has been significantly successful. Cyprus suffers from a protracted conflict, albeit a frozen one. Therefore, while conflict-management-aiming-at-conflict- resolution is not successful, conflict-management-instead-of-conflict-resolution is effective.

A first reason for that is that a military resolution of the conflict seems impossible or at least too costly for either of the two motherlands, both Turkey and Greece. A military clash in Cyprus would probably implicate the two of them, with devastating consequences for both countries in military, political and economic terms, without in addition providing a viable solution of the conflict for any of the two parts. ${ }^{51}$ Despite the military advantage of Turkey in Cyprus, the overall military and political balance between Greece and Turkey could lead to a stalemate in general and in Cyprus. ${ }^{52}$ In addition, the economical and political repercussions would be devastating if not catastrophic, in the case of an all out wat between the two states.

Ironically, the existence of two motherlands which has been a paragon fueling the conflict, turns out in terms of conflict management to be-because of the relative and general balance of power between- a paragon which has led to an abstention from the further use of force in the post-1974 period. Military and economic-political balance, even indirect, constitute all together in such a sense, a factor of successful conflict management in the sense of conflict evasion, since both communities and both states have more to lose than gain because from a potential military conflict.

In addition and for different reasons both communities have significant interest in renewable negotiations without necessarily leading to conflict resolution. On the one hand, the Northern part, finds potential benefits in partially overcoming the diplomatic isolation of the so-called Turkish Republic of Northern Cyprus. On the other hand, the Republic of Cyprus through its participation $n$ the negotiations, apart from the possibility of conflict resolution has eased the tensions with the Northern part and among other things achieved its admission in the EU. Therefore, the continuances of negotiations up to some extent have proved to be mutually benefited, regardless of the potential resolution.

The two motherlands also share a common interest for renewable negotiations as means for the containment of potential violence. Turkey keeps the door to the EU open, while Greece is not forced to extent its military budget because of possible renewal of the conflict.

A third reason enabling a successful conflict managementalthough only partially successful- is the clear division between the two communities. While the long- term occupation and the division have profoundly deteriorated the potential for a solution in the conflict, the "distance" between these two communities and the frozen between them situation have also eased the tensions. Even more, up to some extent such an artificial division, imposed by the occupying force, created certain nostalgia for closer interaction between the two communities which became apparent in the first and second decade of the $21^{\text {st }}$ century.

The success of conflict management in terms of maintaining the abstention from direct violence and the frozen status of the conflict in Cyprus for decades, up to some extent has eased the sense of urgency in terms of resolving the conflict. While the resolution of

${ }^{51}$ Richmond. Ethno-Nationalism, Sovereignty and Negotiating Positions in the Cyprus Conflict Obstacles to a Settlement. 1999:55.

${ }^{52}$ Guvenc S, Egeli S. Changing Military Balances in the Eastern Mediterranean: Implications for Turkey. Turkish Policy Quarterly. 2016;15(1):93-105. 
the conflict up to now has not been achieved, still the stabilization of the conditions on the ground remains a fact. In addition, a resolution of the conflict- of some kind-despite not being the most probable solution is still possible.

Summing up, the inter-communal grievances, the gradual formation of distinct and hostile identities, the problematic institutional formation of the Republic of Cyprus and of this foundational treaties, the role of the motherlands and the international environment paved the way for protracted conflict in Cyprus. Ironically, some of these conditions have also contributed, to the freezing of the conflict as well and therefore to successful conflict management.

Eventually, on the basis of the fore-mentioned characteristics, the common denominators of all members which are implicated in this protracted conflict are first that they share interest in successful conflict management, even without conflict resolution in sight; second that the whole environment of the conflict makes it more likely to have effective conflict management in terms of not resorting to violence at an increasing pace. In such a framework, there is simultaneously a strategic, structural framework which is negative towards conflict resolution and also a framework tending towards effective case management too. In the next part, the specific characteristics of the conflict management in the Israeli-Palestinian conflict are examined and compared to those of the Cyprus conflict.

\section{The Israeli-Palestinian conflict and the failure of conflict management}

If conflict management is to be understood as a pre-step towards conflict resolution it never seemed as doomed to fail as now, regarding the Israeli-Palestinian conflict. If it is to be comprehended as a procedure which is adopted in the face of the failure of conflict resolution in order to ease the tensions it has indeed failed again. ${ }^{53}$

The history of the Israeli-Palestinian conflict is well known, in a rather detailed way. What is important to stress here regarding the theme of this article is that in broad terms we could divide the history do the Israeli-Palestinian conflict into the following major phases: the first phase reaches 1947-1948, when the recognition of Israel takes place, the first Arab- Israeli war and the Naqba. It is the phase which establishes the state of Israel in the Middle East and causes shockwaves to the Arab states and their regimes, which fail both to adjust and to confront this development.

The second phase lasts until 1967 and the Six- Day War, which sowed the seeds of the occupation and of most of the events which followed, during the Israeli-Palestinian conflict. In addition it inflicted a blow on the Arab nationalist regimes and ideology with Nasser being the most prominent figure.

The third phase begins at 1968 with the rise of the PLO lasting until 1974. The "Palestinian national cause" principle was introduced and the PLO on the one hand intensified the Palestinian struggle, while at the same time partially distanced itself from the state interests of other Arab States. It ended with the recognition of the right to selfdetermination of the Palestinians by the UN General Assembly.

The fourth phase "witnessed" the intensification of military struggle of the Palestinians and lasted until 1987-1988 with outbreak of the first intifada and the PLO declaration for the creation of a state

\footnotetext{
${ }^{53}$ In this part the focus is not on a detailed analysis of the Israeli-Palestinian conflict in historical terms but rather an analysis of the conflict-management approach, especially during the post-Kamp David and Oslo accords era.
}

of Palestine. The Intifada marks a whole new era for the IsraeliPalestinian conflict and it can be considered as the beginning of the fifth phase. Through civil disobedience, continuous protests, strikes and clashes of unarmed Palestinians- even children- with the Israeli army, the international pressure on Israel mounted, the Israeli occupation and army were discredited at large.

The tensity and the type of the fight which was conducted by the Palestinians forced the Israeli government into the table of negotiations. By the end of this period the mutual recognition of Israel and PLO in 1993 with the Oslo declaration of principles took place, as well as the Taba Agreement and the election of Yassir Arafat as president of the Palestinian Authority. It is the phase of high hopes for the Israeli-Palestinian conflict, under the influence of regional and international factors as well. ${ }^{54}$

Conflict resolution seemed for the first time to be closing in. At the same time, the defects of the agreement were becoming gradually obvious. The Oslo Accords were not a peace treaty, nor did they resolve the most thorny issues of the conflict. They provided to the Palestinians a partial statehood-in-the-making, with complicated and fragmented authority, while it foresaw that the conflict resolution should have been reached by 1998 . The road to peace was potentially mined from the beginning of the peace effort. In such a sense it bears similarities with the declaration of Cyprus independence, as the defects of fundamental treaties, combined with pre-existing, negative circumstances, eventually re-fueled the root- causes of the conflict.

The last phase begins with the failure of the Camp David summit and the second Intifada, lasting until now. ${ }^{55}$ It is the phase of Palestinian frustration, sporadic intensification of the conflict, decay of the Palestinian Authority on the ground, despite its further international recognitions, internal divisions within the Palestinians and of domination of right- wing or even extreme right wing ideas in Israel.

The history of the Israeli-Palestinian conflict on the one hand condenses up to a significant extent the Israeli-Arab conflict, as well as the regional and global balance of power, throughout these decades, while on the other hand gained gradually its own dynamics, even after it stopped gathering that much of world and regional attention-or at least in the way it did previously. During Cold-War era, the rivalry between the USSR and the US deteriorated possibilities for an effective conflict resolution approach. ${ }^{56}$ The involvement of regional actors, such as Egypt, Syria and Jordan was-and up to some extentstill is profound. However it passed through several different stages, especially since PLO gained momentum and independent strategy from its regional Arab supporters. That situation led to the wellknown violent confrontations with Arab states.

While the incorporation of the Israeli-Palestinian conflict in the framework of the Cold-War and of regional conflicts harmed the prospects of conflict resolution and therefore, the fact that it gathers less attention as an issue of global powers rivalries has done very little

${ }^{54}$ Haberman C. Mideast accord: The Overview; P.L.O. and Israel accept each other after 3 decades of relentless strife. USA: The New York Times; 1993.

(http://www.nytimes.com/1993/09/10/world/mideast-accord-overview-ploisrael-accept-each-other-after-3-decades-relentless.html?pagewanted=all, access. 15-12-2017)

${ }^{55}(2009)$ For a brief timeline of events PLO: History of a Revolution. Qatar: Al Jazeera; 2009.

${ }^{56}$ Slater J. The Superpowers and an Arab-Israeli Political Settlement: The Cold War Years. Political Science Quarterly. 1991;105(4):558-559. 
towards the direction of resolution or of management, despite the high hopes which were raised during the 90 's. ${ }^{57}$

An additional wide variety of reasons were proposed as soon as the initial remarks of non- implementation of the Oslo accords appeared, referring to reasons such as the political impact of the role of settlers and villagers, the issue of refugees, the sharing of water resources, ${ }^{58}$ the struggle for the control of East Jerusalem, ${ }^{59}$ the denial of any of two or both of the sides to achieve viable peace, the lack of unbiased mediator and of will on behalf of the international community to actually pressure towards the direction of peace. Gradually, the accumulation of several factors coincided with a rightwing, "hawkish" turn in Israeli politics, following the murder of Yitzak Rabin and the dominance of Ariel Sharon as well as Benzamin Netanyahu. ${ }^{60}$

In terms of the lack of conflict resolution, the Cyprus and the Israeli-Palestinian conflicts bear some striking similarities. The divergent and hostile identifications of the two communities- at least after some point- constitute the defining point of reference in terms of the root-causes of the conflict. The co-existence of the two communities was approached by both as a problem rather than as an opportunity or at least as Normal situation, at least as soon as the issue of state-genesis came into being. The other common factor has the been the role of the former colonial force- UK- as well as of other international and regional states.

Their role, combined with the prevalence of nationalistic sentiments led to an initial partition plan, which was full of defects, failing to take into account the actual conditions on the ground. It is-parenthetically- important to stress here that the United Nations Special Committee on Palestine-UNISCOP-which was established by the UN General Assembly-UN GA-in 1947 had concluded that the population composition was out of a total of $1.846 .000,1,203,000$ were Arabs and 608,000 were Jews, while land ownerships statistics showed that Arabs were in possession of more land that the Jews in every district reaching throughout the whole of Palestine an $85 \%{ }^{61}$

The proposal of the Arab states was that of a unitary state with protective guarantees for all minorities. Again, a common element with the conflict in Cyprus emerges, which is the will of the majority of the population to create a unitary state, while the minority in both cases wished for partition. ${ }^{62}$ UNISCOP proposal was partition which provided $55 \%$ of the territory to the Jewish population and $45 \%$ to the Arab population. ${ }^{63}$ Contrary to that, the sub-committee of the Ad Hoc Committee on the Palestinian Question, which was established by the General Assembly following the UNISCOP report, advocated the conversion of Palestine into an independent state, denounced the

${ }^{57}$ Slater J. Regarding the raise of such hope, see for example: A Palestinian State and Israel Security. Political Science Quarterly. 1991;106(3):411.

${ }^{58}$ Slater. A Palestinian State and Israel Security. 1991. 413 p.

${ }^{59}$ Pearson. Dimensions of Conflict Resolution in Ethno political Disputes. 2001;38(3):278.

${ }^{60}$ Sasley BE. Israel's Right Turn, Behind Bibi's Victory, Foreign Affairs. 2015.

${ }^{61}$ The Arab population increase was the outcome of natural causes, while of the Jewish population, mostly the result of immigration.

General Assembly, official records of the second session of the general assembly supplement no. 11 united nations special committee on palestine 1947. p. $13-15$

Khalidi W (1997) Revisiting the UNGA Partition Resolution, XXVII (1) Journal of Palestine Studies. 1997:11.

${ }^{62}$ United Nations Special Committee On Palestine, Chapter IV. p. 8-12.

${ }^{63}$ Hammond J. The Myth of the UN Creation of Israel. Foreign Policy Journal. 2010 partition plan and practically it suggested that it was up to the people of this state to determine its structure and its future. ${ }^{64} \mathrm{UN}$ GA resolution 181 endorsed UNISCOP plan for partition and requested from the UN SC to take all necessary measures for the implementation of this plan. ${ }^{65}$ Before the UN SC the state of Israel was declared and the first Arab- Israeli war broke out.

On top of the fore-mentioned elements, another one which is common in both cases is that from the beginning, the plan for the resolution of the conflict which was at the point emerging was full of defects. As in Cyprus, in Palestine too, the adopted plan reinforced the existing grievances and distinctions instead of resolving them or at least easing them. In addition, the regional and wider international actors contributed into the intensification rather than the easing of the conflict.

It becomes apparent that in spite of the differences there are striking similarities between the two cases regarding the building of the conflict, its intensification, as well as the failure of resolution to the conflict. Again, as in the Cyprus conflict, the long lasting occupation added numerous problems on top of the already existing one: possession of land, refugees, demographic change, economic recession, use of water and natural resource, settlements, wall on the Palestinian territory, use of violence, inequalities, conflicting identities are all factors which have shaped the landscape of protracted conflict.

The differences become emphatically present when from conflict resolution we move onto conflict management. While in Cyprus as it is stated above conflict management has been successful in terms of freezing the conflict, in relation to the Israeli-Palestinian it is a complete failure. The main approach of the article is that the defining event in both cases is the existence of occupation. Before the two occupations there are inter-communa grievances or even conflicts. After the occupations as it is analyzed above, one of the two parts is dominant on the ground and a whole set of new problems arise. Therefore, the differences in relation to conflict management are up to a large extent-but not solely-the outcome of the characteristics of the occupations. We need to bear in mind of course that the differentiation in their characteristics are on their turn the outcome of a number of other factors and not of the benevolence or not of the occupying force.

The Israeli occupation itself has been up to some extent different from that of Turkish troops in Cyprus, because of the objective conditions too. In both cases, occupation constitutes a constant act of aggression and therefore is a defining reason for the non- resolution of the protracted conflicts. However, in the case of Cyprus the occupation keeps the conflict at a frozen status, since the occupying force "guarantees" the ongoing partition and distance between the two parts. The occupation of Northern Cyprus keeps the two communities divided in a way that minimizes or at least restrains their inter-linkage. In Cyprus both communities possess territory and state (hood). They also stand on a relatively equal position.

Even if Turkish military presence is stronger than the one of Cyprus and Greece in Cyprus, the overall balance between Turkey on the one hand and the Republic of Cyprus and Greece on the other hand, in military, diplomatic and economic terms bring balance to the situation, which makes it irrational for any of the two sides to look for a complete military domination and-concerning the occupying force- expansion of its occupation. The "static" nature of ${ }^{64} \mathrm{UN}$. "Ad Hoc Committee on the Palestinian Question Report of SubCommittee 2". USA; 1947.

${ }^{65}$ UN GA. A/RES/181(II), Future Government of Palestine. 1947. 
the occupation depicts and strengthens a strategic, structural approach tending towards the freezing of the conflict and in such a sense toward successful conflict management. In addition, it must be taken into account that the inherent characteristics of the implicated partsRepublic of Cyprus and Northern Cyprus, Turkey and Greece- have not changed in ways which could reignite the conflict.

On the other hand, the Israeli occupation depicts and exercises the constant and expansive denial of the right of the Palestinians to exist as state and as people. The type of the Israeli occupation does not constitute a factor of separation of the two communities but a paragon of continuous merging, albeit in an unequal and erosive for the one community way.

Several characteristics are indicative of this condition. For example, Israel is denouncing the exercise of its occupation over the Gaza strip, limiting thus as much as possible the legal restraints of its actions and its obligation to respect the Fourth Geneva Convention. ${ }^{66}$ While it is also true that Turkey attempted to justify its illegal occupation of Northern Cyprus on the basis of the system of guarantees as well as to provide it with some legitimacy through the so-called Turkish Republic of Northern Cyprus, the Israeli occupation has moved several steps further both in practice and in legal term. Conditions such as the confiscation of Palestinian land, the illegal building of the Israeli wall on Palestinian land,${ }^{67}$ the expanding settlements, the constant violations of the Oslo accords, the continuous imprisonment even of minors, the extrajudicial killings and the waves of disproportionate violence and on the other hand legal arguments such as those orientating from the pseudo-"disengagement" of Israel from the Gaza strip, ${ }^{68}$ constantly deteriorate the root- causes of the conflict as well as its manifestations.

The Israeli occupation keeps the two communities and the two authorities bound together in a constant situation of unequal and unfair treatment by the stronger part- Israel- through permanent use of violence, violation of law and of human rights.

It is in this framework that Israel is expanding both officially and unofficially its jurisdiction over the West Bank and the Gaza Strip through military courts and arbitrary arrests and raids, ${ }^{69}$ partially on the basis of the complex and unbalanced in favor of the state of Israel

\footnotetext{
66"Israel has without doubt at all times relevant to the mandate of the Mission exercised effective control over the Gaza Strip. The Mission is of the view that the circumstances of this control establish that the Gaza Strip remains occupied by Israel" and "Gaza remains occupied territory and ...Israel is obliged to comply with the Fourth Geneva Convention in its actions in Gaza"

'Report of the United Nations Fact Finding Mission on the Gaza Conflict'. UN Doc. A/HRC/12/48, 85. 2009. 276 p.

'Report of the Independent Fact-Finding Committee on Gaza: No Safe Place' (presented to the League of Arab States). 2009. 16 p.

${ }^{67}$ Orakhelashvili A. Legal Consequences Of The Construction Of A Wall In The Occupied Palestinian Territory: Opinion And Reaction. Journal of Conflict and Security Law. 2006;11(1):119.

${ }^{68}$ The analysis of the Gaza strip as a "hostile territory" due to the governance of this area by Hamas- a term which can find no justification in international legal treaties- poses a clear case of international law manipulation up to such an extent that the evacuation of Gaza strip practically meant that Israel remained the occupying force but with none of the obligations that an occupant has to bear.

Darcy S. An Enduring Occupation: The Status of the Gaza Strip from the Perspective of International Humanitarian Law. Journal of Conflict and Security Law. 2010;15(2):225-228.

${ }^{69}$ Cavanaugh K. The Israeli Military Court System In The West Bank And Gaza. Journal of Conflict \& Security Law. 2007;12(2):199-201.
}

regulations of jurisdiction of the Kamp David and Oslo accords, ${ }^{70}$ but also in violation of them. Especially after the outbreak of the second Intifada, the extent and intensification of Israeli occupation has significantly deteriorated. Either painted as a "benevolent" occupation $^{71}$ or in the bleak terms of ordinary life under the occupation, ${ }^{72}$ the truth is that the "crackdown" on Palestinians' rights have created a hopeless situation among them.

The continuation of the occupation and the violation of the Oslo accords by Israel have seriously undermined over time even the halfsteps institutionally speaking of the existent agreements between Palestine and Israel. In such a sense, because of the occupation, the Palestinian Authority is becoming also the victim at least in relation to it's moral and political validity, apart from the erosion in praxis of its institutional capacity. The two- state solution is practically cancelled up to the extent that the Palestinian Authority is transformed into a pseudo-state, ${ }^{73}$ with minimal authority, while the economic situation continuously deteriorates. Inequality between Israel and Palestine in terms of territory, sovereignty as well as economic conditions also deteriorates. ${ }^{74}$

Thus, Israeli occupation on the one hand sharpens the root- causes of the conflict and on the other hand establishes as a concrete belief that not only the resolution of conflict is impossible but also that any type of management is designed to unilaterally enhance the Israeli agenda, indicating an Israeli inherent lack of willingness not only for conflict resolution but also for some type of conflict- management, capable of easing the tension.

This factor constantly fuels violence leading to incapacity even to

${ }^{70}$ West Bank and Gaza were divided into zones A, B and C. Civil powers and responsibilities were transferred from the Israeli Civilian Authority to the Palestinian Legislative Council while in Zone C, were transferred the powers and responsibilities not relating to territory. According to the Oslo II Accords, the Palestinian National Authority took over partial jurisdiction over the legal affairs of the West Bank and the Gaza Strip, namely except the offences which were committed inside Jewish settlements, Israeli military installations, and by or against Israelis. In the West Bank, the Palestinian Authority was given jurisdiction over all the offences which were committed by Palestinians or non-Israelis in the areas under its own control, while Israel retained jurisdiction over offences committed inside all of the West Bank by Israelis, against Israelis and of security or terrorism nature, in Zone B. Concerning civil matters, the authority inside Gaza and the West Bank was fully transferred to the Palestinian authorities, exempting cases against Israelis and the State of Israel or its agents. Co-operation between Israeli and Palestinian authorities was also foreseen.

Cavanaugh The Israeli Military Court System In The West Bank And Gaza. $196 \mathrm{p}$.

${ }^{71}$ Aronson G. When it Comes to Israeli Occupation, Better is not Good Enough. Middle East Institute; 2015.

${ }^{72}$ Hamze A. 10 Things Palestinians Can't Do Because Of The Israeli Occupation. Huffington Post, 2016.

Staton B. The grinding reality of life under Israeli occupation. Middle East Eye. 2014.

${ }^{73}$ Indicatively see: Kuttab D. Palestinians need own strategy to end occupation. Al Monitor. 2017.

Ragson, Abbas adviser: Without hope for a Palestinian state, 'PA would collapse'. Jerusalem Post; 2017.

The Economist, The hopes for peace and Palestinian statehood fade away. 2016.

Fadl MA. No hope yet for independent Palestinian state. The Arab Weekly. 2017.

${ }^{74}$ Newman D, Falah G. Bridging the gap: Palestinian and Israeli discourses on autonomy and statehood. Transactions of the Institute of British Geographers. 1997;22(1):111-115. 
manage the conflict, due to the expansive nature of the occupation. The Israeli occupation is "growing" economically-wise, land-wise and violent-wise. Of course behind this specific nature of occupation lie a number of elements: no extent of even relative balance of power, at any level; little actual support for the Palestinian people both regionally and internationally by other states; continuous sense of fear among the people of Israel and the dehumanization of the other side; an international environment which when it is not indifferent is proven even catastrophic for the management of the conflict.

Long standing occupation deepens the chasm between the two communities, adding anger, grievances and stereotypes. The psychological aspect of the conflict is obvious on both sides. As researches had indicated in the past, only a very small portion of Palestinians are keen in having social relations with Jews. ${ }^{75}$

More recent polls have shown the expansion of the feelings of bicommunal insecurity. For example, in a Joint Israeli Palestinian Poll of June 2015 conducted by the Harry S. Truman Research Institute for the Advancement of Peace at the Hebrew University of Jerusalem and the Palestinian Center for Policy and Survey Research (PCPSR) in Ramallah, the findings were that " $56 \%$ of Palestinians think that Israel's goals in the long run are to extend its borders to cover all the area between the Jordan River and the Mediterranean Sea and expel its Arab citizens. 25\% think the goals are to annex the West Bank while denying political rights to the Palestinians. $43 \%$ of the Israelis think that the Palestinian aspirations in the long run are to conquer the State of Israel and destroy much of the Jewish population in Israel; $18 \%$ think the goals of the Palestinians are to conquer the State of Israel". ${ }^{76}$

The psychological factors intensity violence having at their basis both the inter-communal violence as well as its consequences, such as financial loss, also shape at large the continuation of the vicious circle of the conflict. ${ }^{77}$ The analysis of the psychological factors constitute a distinct area of analysis especially in the framework of protracted conflicts and incorporate a variety of interactions. The main possibly has been the one advocating the inter linkage of violence in protracted conflicts with each specific ideology, since the latter "....constitutes a coherent worldview often prevalent in one's culture, which can provide a sense of meaning in the face of individual and collective threats". ${ }^{78}$

It is argued that these psychological attitudes are framed in the Israeli-Palestinian conflict on the basis "... of eight belief themes: justness of the goals, victimization, and security, and positive

\footnotetext{
${ }^{75} \mathrm{Mi}$ ' ari M. Attitudes of the Palestinians towards Normalization with Israel. Journal of Peace Research. 1999;36(3):339-340.

${ }^{76}$ ProCon.org. Is a Two-State Solution (Israel and Palestine) an Acceptable Solution to the Israeli-Palestinian Conflict. 2015. Palestinian Center for Policy and Survey Research (PSR)

It must not be underestimated though that the inter-communal relations are much more complicated, on the basis of the different social classes, ages etc. Not all emotions or positions are equally and always negative. On the contrary, there are constant interactions- although not always of a positive nature- within the labor market and concerning trading, generating a variety of emotions. Mi' ari, Attitudes of the Palestinians towards Normalization with Israel. $341 \mathrm{p}$. ${ }^{77}$ Price, Richard H, Nam Choi J, et al. Links in the Chain of Adversity Following Job Loss: How Financial Strain and Loss of Personal Control Lead to Depression, Impaired Functioning, and Poor Health. Journal of Occupational Health Psychology. 2002;7:302-12.

${ }^{78}$ Lavi I, Canetti D, Sharvit K, et al. Protected by Ethos in a Protracted Conflict? A Comparative Study among Israelis and Palestinians in the West Bank, Gaza, and East Jerusalem. Journal of Conflict Resolution. 2012;1:4
}

collective self-image, delegitimization of the adversary, patriotism, unity, and peace". ${ }^{79}$ These themes synthesize the psychological stance within the conflict, in connection with the specific phase of the latter as well as the background ideological admissions of the individuals, eventually leading to the portray of the other group as inherently hostile-even inhumane-or not. ${ }^{80}$

The perceived by Israel as Palestinian-oriented security threat has shaped catalytically the Israeli stance on the matter. Several incidents have fueled such fears, despite the shift of PLO policy since the " 70 s towards the recognition of Israel and the restrain of its ambitions regarding a future Palestinian state in terms of territory as well as access to arms potentially threatening Israel. On the other hand, the continuous occupation has shaped the sentiment "of summed-a determination to exist through being steadfast and rooted to the land", which is combined with the impact of trauma because of the occupation. ${ }^{81}$ While it is difficult-if not impossible-to analyze in the context of this article the social and political consequences of these psychological conditions, it is proven that the effect of the continuous violence is that of "dehumanization of life under military occupation" ${ }^{82}$ The effects on the peace process are obvious and not difficult to be captured.

On the basis of the fore-mentioned reasons, a structural, strategic, negative attitude towards not only conflict resolution but also conflict management is formulated. Violence is not managed therefore at any point. In some cases, merely exhaustion, achievement of one- sided goals or repressive measures manage to suppress the violence, while when none of these three constituents can keep it at a low level, it breaks out, more or less "naturally".

Having said all of the fore- mentioned and partially on the basis of them, the approach of the current paper is that another, structural reason for the inefficiency of conflict resolution as well as management must be sought; namely the ideological transformations of Israel and the inherent fear for its own existence; such a condition is not only a mechanical outcome of regional, external balance of power but also of internal reasons, such as the Arab minority and the way it is approached by the Jewish majority as well as by the concept of the transformation of Israel to a "Jewish" state, which objectively undermines its internal coherence.

Eventually it is the internal reformulation of the Israeli society and state in terms of hegemonic principles, which when combined with the rest of the other conditions undermine the Israeli participation in sincere and fruitful conflict resolution as well as management procedures. ${ }^{83}$ This (dis-)orientation- in terms of seeking peace-of Israel affects its stance in the negotiations with the Palestinians, especially during the Netanyahu era. ${ }^{84}$

The transformation of the state of Israel is an international taboo of course and it can only be briefly mentioned here. It came at the epicenter when UN Economic and Social Commission for Western Asia released its report entitled "Israeli practices towards the Palestinian people and the Question of Apartheid".

\section{${ }^{79}$ Ibid. p. 4.}

${ }^{80}$ Ibid. p. 5.

${ }^{81}$ Nguyen-Gillham V, Giacaman R, Naser G, et al. Normalizing the abnormal: Palestinian youth and the contradictions of resilience in protracted conflict. Health and Social Care in the Community. 2008;16(3):291-292.

${ }^{82}$ Ibid. p. 294.

${ }^{83}$ Gavison R. Culture, society, law and adjudication. International Journal of Constitutional Law. 2013;11(4):1115-1116.

${ }^{84} \mathrm{Kuttab}$ D. Israel appears disoriented on peace talks. Al Monitor. 2014. 
The report dared to pose the long floating question of whether Israel is turning into an apartheid state. In the report it mentioned that "... if constitutional law defines the State as racial in character-as in Israel (as a Jewish State), and apartheid South Africa (as a whiteAfrikaner State)-movements against racial discrimination not only lack this crucial legal resource but find themselves in the far more dangerous position of challenging the regime itself. Such a challenge will naturally be seen by regime authorities as an existential threat and be persecuted accordingly. In short, it is crucial for a finding of apartheid to establish whether the State's constitutional law (the Basic Law in Israel) renders discrimination illegal or renders resistance to discrimination illegal". ${ }^{85}$

The report identifies first a "demographic engineering" of the state of Israel in order "to establish and maintain an overwhelming Jewish majority in Israel", second, a ban on challenges to racial domination, third the promotion by the state of Jewish nationalism, and fourth the Apartheid through fragmentation of the Palestinian people. ${ }^{86}$ On the basis of reviewing Israeli practices in accordance with the list of inhuman acts which are described in the Apartheid Convention, the report reaches a stunning and impressive conclusion: “... Israel is guilty of the crime of apartheid". ${ }^{87}$

While the report is of course not binding for the UN, nor Does it "express" the UN view on the issue, it still poses a ground-breaking review of Israeli state policies. In addition, it shows the structural transformation of the state of Israel on the basis of which one may suggest that conflict resolution and conflict management are doomed to fail.

The question about whether Israel is structurally incapable of participating in conflict resolution or even management with the Palestinians is not as novel as it seems though. Within the Israeli legaland not only legal- community, the military occupation following the 1967 war, the unilateral annexation of the West Bank and of the Golan Heights are identified as reasons for the erosion of the democratic foundations of the state of Israel, due to the prevalence of a Jewishcentered orientation as a dominant ideology. In addition militarism and patriarchy have also been criticized as deeply conservative principles, traced in a Jewish orthodoxy, which bears also implications regarding conflict management. ${ }^{88}$

The theme of the article does not allow a separate analysis of these factors separately. It merely intends to show through the reference to them that a strategically negative stance of Israel has emerged which makes impossible even the management of the conflict and which is reflected up to some extent in the position of the Palestinian public as well.

${ }^{85} \mathrm{UN}$ Economic and Social Commission for Western Asia, Israeli practices towards the Palestinian people and the Question of Apartheid. p. 20.

${ }^{86}$ Israeli practices towards the Palestinian people and the Question of Apartheid. p. $21-42$.

${ }^{87}$ Ibid p. 53

${ }^{88}$ Barzilai G. Analysis of Israelis [Jews and Arab-Palestinians]: exploring law in society and society in law. International Journal of Law in Context 2015;11(3):367.

Ram U. The Time of the 'Post' Nationalism and the Politics of Knowledge in Israel (Resling). 2006.
Such characteristics, when combined with deep-rooted security fear, a policy of expansion in order to gain strategic depth, make it almost impossible to co-exist peacefully with the "other"-in this case the Palestinians. Under such an interpretation, the Israeli state is seen as inherently or at least structurally incapable or unwilling to participate in successful conflict resolution or conflict management in it's current phase

\section{Conclusion}

In this paper I tried to analyze the Israeli- Palestinian conflict through a comparison with another major protracted conflict, that of Cyprus, in order to show that there are some inherent conditions within the primary that make not only conflict resolution but also conflict management, in furtherance or even instead of resolution, highly unlikely. While there are common elements between the two conflicts which make conflict resolution a distant goal, the course of the two conflicts is contradictory when the case of conflict management arises. Regarding this second issue, conflict management in the case of Cyprus is successful on the basis of a general balance of power which makes it rational for all implicated parts not to resort to the use of force, raising therefore a positive towards easing the tension stance.

In the case of the Israeli-Palestinian conflict, the totally unequal balance of power creates the framework for an expanding occupation and therefore a structurally negative stance towards both conflict resolution and conflict management. In addition, the structural transformation of Israeli political life, of its hegemonic values and eventually of the Israeli state within the conflict prevents not only conflict resolution but also a conflict-management-instead-ofresolution, approach.

In such a sense, successful conflict management is out of the question in the Israeli-Palestinian conflict unless the position of Israel undergoes a U-turn in relation to the establishment of the Palestinian state and the rights of the Palestinians. Such a U-turn though might be the outcome either of a lost conflict or of significant international pressure which at this point seems rather impossible. This is therefore why, while in the Cyprus conflict, at least conflict management remains an achievement, in the Israeli-Palestinian conflict, the vicious circle of occupation and violence will continue determining the unfolding events.

\section{Acknowledgements}

Themistoklis Tzimas: (1981), Post-doc Researcher, 2017, University of Macedonia, Thessaloniki, Greece: "Transformations of State- Sovereignty"; PhD in Public Law and Political Science, Aristotle University of Thessaloniki, Faculty of Law: "Human Security within the Collective Security System"; current main interest: states of limited sovereignty.

\section{Conflict of interest}

The author declares no conflict of interest. 